\title{
A Detached Cucumber Fruit Method to Screen for Resistance to Phytophthora capsici and Effect of Fruit Age on Susceptibility to Infection
}

\author{
A. J. Gevens, Department of Plant Pathology, Michigan State University, East Lansing 48824; K. Ando, Department \\ of Horticulture, Michigan State University, East Lansing 48824; K. H. Lamour, Department of Entomology and \\ Plant Pathology, The University of Tennessee, Knoxville 37996; R. Grumet, Department of Horticulture, Michigan \\ State University, East Lansing 48824; and M. K. Hausbeck, Department of Plant Pathology, Michigan State Univer- \\ sity, East Lansing 48824
}

\begin{abstract}
Gevens, A. J., Ando, K., Lamour, K. H., Grumet, R., and Hausbeck, M. K. 2006. A detached cucumber fruit method to screen for resistance to Phytophthora capsici and effect of fruit age on susceptibility to infection. Plant Dis. 90:1276-1282.

Identification and utilization of resistance to Phytophthora capsici could provide the basis for a viable management strategy against cucumber fruit rot, a persistent threat in cucumber (Cucumis sativus) production. Our objectives were to develop a method for testing detached, nonwounded, cucumber fruit for resistance to $P$. capsici, and to screen cucumber cultivars and plant introductions (collectively referred to as cultigens) for resistance. Four $P$. capsici isolates (differing in their sensitivity to the fungicide mefenoxam and compatibility type) were compared for their fruit infection capability in 1999 and 2000. No significant differences were found among isolates, and a single isolate was used for all subsequent screens. From 1999 to 2004, 480 cucumber cultigens were grown according to standard practices at Michigan State University research farms in four fields with no history of $P$. capsici. Commercially mature fruit were harvested, inoculated with $P$. capsici, and rated for lesion diameter, pathogen sporulation diameter, and density of pathogen sporulation. Although no fruit exhibited complete resistance to $P$. capsici, some cultigens exhibited limited pathogen sporulation. In the process of screening, it was observed that younger, smaller fruit were comparatively more susceptible than older, larger fruit. Replicated trials with hand-pollinated fruit showed that the transition from susceptible to more resistant appeared to coincide with the transition from the period of rapid fruit elongation to the period of increased fruit diameter. This is the first report using a nonwounded fruit screen to analyze cucumber resistance to $P$. capsici.
\end{abstract}

Additional keywords: accessions, disease resistance, pickling cucumber

Fruit rot caused by the fungal-like oomycete pathogen, Phytophthora capsici Leonian, has become a limiting factor for cucumber (Cucumis sativus) producers in Michigan, and has been reported in several regions of the United States $(8,17)$. P. capsici has been found to infect a wide range of Solanaceous and Cucurbitaceous hosts worldwide $(6,7,9)$. Cucumber fruit are especially susceptible. Fields of healthyappearing vines have been bypassed, and harvested loads have been rejected by processors due to widespread fruit rot (8). While the root and crown of the cucumber plant may become infected by $P$. capsici, infection of these tissues primarily occurs

Corresponding author: M. K. Hausbeck

E-mail: hausbec1@msu.edu

* The $\boldsymbol{e}$-Xtra logo stands for "electronic extra" and indicates the HTML abstract available on-line contains two supplemental tables not included in the print edition.

Accepted for publication 22 May 2006.

DOI: 10.1094/PD-90-1276

(C) 2006 The American Phytopathological Society during the seedling stage. Fruit may become infected while in the field, with the disease progressing during storage and transit so that the symptoms and/or signs become evident only after delivery to the processor or retailer (8).

Pathogen infection is most obvious as white, powdery growth resulting from sporangia and/or oospores produced on the surface of infected cucumber fruit. In the presence of free water, each sporangium releases 20 to 40 motile zoospores capable of causing widespread plant infections in a short period of time (8). Oospores are overwintering, long-term, primary survival structures that form when the A1 and A2 compatibility types (CTs) of $P$. capsici come together $(4,13)$. Both CTs have been identified from fields sampled in Michigan and other vegetable-producing states $(2,8$, 11,20). Germinating oospores infect the crop in the spring (14).

While crop rotation is the foundation of disease management, the long-term survivability of oospores limits the effectiveness of this strategy for $P$. capsici $(8,14,20)$. Historically, growers have relied on the phenylamide fungicide mefenoxam to manage this disease, but resistant $P$. cap- sici isolates have been identified in Michigan, North Carolina, and New Jersey $(11,12,15,17,18)$. While other fungicides are available, they provide varying levels of control, and the required frequent applications increase production costs. In some cases, lengthy preharvest intervals limit fungicide use during fruit development (8).

Whenever available, genetic resistance is a preferred plant disease management tool. Frequently, screening for disease resistance is performed on seedlings because of space and time considerations, as has been done for cucumber with respect to several fungal pathogens (5). However, disease resistance in seedlings is not known to be correlated with fruit resistance, and comparative susceptibility of cucumber vines and fruits in the field suggests that more than one mechanism of host resistance may be involved. In pepper, resistance to $P$. capsici is under different genetic control in different tissue types (21,22).

Since the primary impact of $P$. capsici in field epidemics is on fruits, a methodology for screening cucumber fruit for resistance to this pathogen was needed to evaluate cultigens. Our research objectives included (i) developing an effective methodology for screening cucumber fruit for resistance to $P$. capsici, (ii) screening the fruit of $C$. sativus cultigens to identify resistance for breeding, and based on preliminary observations made during screening, and (iii) characterizing the effect of fruit age on susceptibility to $P$. capsici.

\section{MATERIALS AND METHODS}

Screening methodology. Isolate maintenance and selection. Fresh cultures of each isolate were obtained by transferring agar plugs from long-term stock cultures (stored at $20^{\circ} \mathrm{C}$ in sterile microcentrifuge tubes with $1 \mathrm{ml}$ of sterile water and one sterile hemp seed) onto V8 juice agar (16 $\mathrm{g}$ agar, $3 \mathrm{~g} \mathrm{CaCO}_{3}, 160 \mathrm{ml}$ unfiltered $\mathrm{V} 8$ juice, and $840 \mathrm{ml}$ distilled water). Cultures were maintained at room temperature under continuous fluorescent lighting. Sevenmillimeter-diameter agar plugs from the margins of actively growing colonies were transferred to new V8 juice agar and maintained under the conditions indicated above.

P. capsici isolates OP97, SP98, SFF3, and SF3 were selected for comparison of 
cucumber fruit disease response in 1999 and 2000. Isolate notation refers to cultures maintained in the laboratory of M. K. Hausbeck at Michigan State University (MSU). All four isolates were collected in Michigan from infected cucurbit crops, and were characterized according to compatibility type (CT) and sensitivity to mefenoxam (11). Both OP97 (A1 CT) and SP98 (A2 CT) are fully sensitive to mefenoxam. Isolate SFF3 is an A2 CT and is insensitive to mefenoxam. Isolate SF3 is an A1 CT with intermediate sensitivity to mefenoxam. For each $P$. capsici isolate, disease was evaluated on 16 fruit per cultigen at 3 days postinoculation (dpi) on 66 cucumber cultigens in 1999 and 58 cultigens in 2000. Disease parameters recorded included sporulation density $(0=$ none, $1=$ light, 2 = moderate, 3 = heavy sporulation), diameter $(\mathrm{cm})$ of white powdery sporulation, and diameter $(\mathrm{cm})$ of watersoaked lesions (visible dark discoloration on the fruit surface). Data were subjected to analysis of variance using the PROC MIXED procedure of SAS (SAS Institute Inc., Cary, NC), and means were compared using Fisher's protected LSD test $(P=$ $0.05)$.

Inoculation evaluation. With the exception of the zoospore method (described below), all inoculation tests were conducted with the following parameters. A 7mm-diameter plug of actively expanding $P$. capsici containing mycelia and sporangia was used to inoculate commercially mature fruit $(2.5$ to $5.1 \mathrm{~cm}$ diameter $)$ that were placed in aluminum trays and covered with plastic wrap. A wet paper towel was placed inside each incubation chamber to provide $100 \%$ relative humidity. Trays were exposed to constant overhead fluorescent lighting at 23 to $25^{\circ} \mathrm{C}$. Fruit were evaluated for disease 3 dpi by measuring three parameters: water-soaked lesion diameter, sporulation diameter, and sporulation density. In the first test, fruit were nonwounded, and a sterile, plastic microcentrifuge tube (with the cap removed) was placed over the agar plug and fixed to the fruit with petroleum jelly. In a second test, fruit were wounded by penetrating the fruit surface with a sterile syringe needle at the site of inoculation. Plastic microcentrifuge tubes were placed over the inoculum plug and sealed to the fruit surface. Placing microcentrifuge tubes over mycelial/ sporangial plugs was compared with inoculation without tubes in a third test with nonwounded fruit.

In a fourth test, zoospore inoculum was prepared by placing a 7-mm-diameter plug of a 7-day-old culture in a sterile $1.5-\mathrm{ml}$ plastic microcentrifuge tube with $1 \mathrm{ml}$ of sterile, deionized water. The mixture was incubated at $4^{\circ} \mathrm{C}$ for $20 \mathrm{~min}$, followed by a 20 -min incubation at 23 to $25^{\circ} \mathrm{C}$ to induce zoospore release. A 50- $\mu$ l droplet of zoospore suspension was applied to the surface of each nonwounded fruit and covered with a sterile $1.5-\mathrm{ml}$ microcentrifuge tube (with the cap removed), and fixed to the fruit with petroleum jelly. All other experimental conditions and disease evaluations were carried out as described above. Each of the four inoculation tests was conducted on four fruit per cultigen for each of five cultigens (ACX 5002, Cross Country, Discover, HMX $8461 \mathrm{~F} 1$, and PI 227209). Inoculum tests were run as preliminary studies to refine the technical aspects of the fruit screen.

Germ plasm screening. Cucumber screen 1. Cucurbit germ plasm accessions were provided by the United States Department of Agriculture, Agricultural Research Service, National Plant Germplasm System (USDA-ARS-NPGS), North Central Regional Plant Introduction Station (NCRPIS), Ames, IA. C. sativus germ plasm was chosen either with phenotypic characteristics similar to those of commercial pickling cucumbers (i.e., 'Vlaspik') or with some previously documented resistance to other fungal pathogens. Germ plasm descriptions can be found at the USDA-ARS-NPGS website. In addition, newly released commercial cucumber hybrids were also screened. A total of 333 cultigens were screened during 1999 to 2004 (Table 1). The pickling cucumbers 'Vlaspik' (in 1999, 2000, 2002 to 2004) or 'Vlasspear' (in 2001) were grown as commercial standards.

Cucumbers were grown according to standard management practices in fields with no history of P. capsici at the Michigan State University Plant Pathology Farm, East Lansing (3). In early June, cucumbers were direct-seeded in rows that were 61.0 $\mathrm{cm}$ apart with an in-row plant spacing of $30.5 \mathrm{~cm}$. Rows were bedded and covered in black polyethylene mulch with submulch drip irrigation for weed control and overall plant health maintenance. Pest control and fertilization were carried out according to standard commercial practices (3). Commercially mature (5.1- to 7.6-cm-diameter) fruit were harvested, subjected to a 5-min immersion in a $5 \%$ sodium hypochlorite solution, then rinsed in distilled water. Fruit were allowed to dry under ambient conditions and labeled according to cultigen. Fruit were harvested from the field on four separate occasions per season after observation of the first

Table 1. Numbers of cucumber (Cucumis sativus) cultigens screened for fruit resistance to Phytophthora capsici in screen 1

\begin{tabular}{lcccc}
\hline & \multicolumn{4}{c}{ Cultigens } \\
\cline { 2 - 5 } Year & Screened & $\begin{array}{c}\text { Plant } \\
\text { introductions }\end{array}$ & Commercial & $\begin{array}{c}\text { Selected for } \\
\text { reevaluation }\end{array}$ \\
\hline 1999 & 78 & 39 & 39 & 25 \\
2000 & 36 & 13 & 23 & 29 \\
2001 & 31 & 13 & 18 & 13 \\
2002 & 52 & 41 & 11 & 12 \\
2003 & 41 & 25 & 16 & 16 \\
2004 & 95 & 73 & 22 & 12 \\
Total & 333 & 204 & 129 & 107 \\
\hline
\end{tabular}
varied for each cultigen due to physiological differences in development. Two to 10 fruit were collected for each harvest, and nonwounded fruit were inoculated and rated for disease as indicated above.

Cultigens whose fruit exhibited limited pathogen sporulation were rescreened in subsequent years. The criterion for rescreening was a sporulation density of $\leq 1.0 \mathrm{~cm}$. Forty-five cultigens were screened in two or more years (Table 2), as they continually exhibited a mean sporulation density of $\leq 1.0 \mathrm{~cm}$. Thirty-one $(69 \%)$ of the cultigens selected for rescreening were plant introductions (PIs); the remaining 14 were commercial cultivars (Table 2 ). Of the 25 cultigens selected for rescreening in 1999, 20 (80\%) were PIs and only 5 were commercial cultivars (Table 2). In 2000, a total of 29 cultigens were selected; $20(69 \%)$ were PIs and 9 were commercial cultivars. In 2001 to 2003,12 to 16 cultigens were rescreened; more than half of these cultigens were PIs. Eight of the 12 cultigens selected for rescreening in 2004 were commercial cultivars (Table 2).

Cucumber screen 2. An additional cucumber fruit screen was carried out in 2003 at the Michigan State University Horticulture Research and Teaching Center (HRTC), East Lansing. A set of $150 \mathrm{cu}-$ cumber accessions was supplied by the NCRPIS, Ames, IA. The first 100 genotypes tested were selected based on isozyme data to provide a representative sample of the cucumber germ plasm with maximum genetic variance (10). Another 50 accessions that had been selected for a separate study (1) based on possible variation in plant architecture and growth habit were also included in the fruit disease screening. Seeds were sown in the greenhouse and 14-day-old seedlings were transplanted to the MSU-HRTC in a nonreplicated trial on a field with no history of $P$. capsici infestation. Seedlings were planted $0.5 \mathrm{~m}$ apart in 3.7 - $\mathrm{m}$-long singlerow plots with $1.5 \mathrm{~m}$ between rows. Plastic mulch was used to control weeds and commercial pest control was applied (3). Irrigation was provided by rain or overhead irrigation to $\geq 25 \mathrm{~mm}$ per week.

Harvested fruit from the standard cultivar Vlaspik, (provided by Seminis Vegetable Seed Inc., Oxnard, CA) and test geno- commercially mature fruit. Harvest dates 
types were inoculated as previously described. Four to eight fruit were tested for each genotype. Initial fruit examination was made 4 dpi. Fruit were scored for presence of pathogen sporulation, watersoaked lesions, or no symptoms. Fruit with no symptoms at 4 dpi were monitored daily and maintained for further observation for a minimum of $10 \mathrm{dpi}$, or until the occurrence of water-soaked lesions and pathogen sporulation.

The PIs identified in 2003 for which $<50 \%$ of the tested fruit exhibited pathogen sporulation at 10 dpi (PIs: 249561 Thailand, 255937 Netherlands, 263047 Russia, 288990 Hungary, and 304805 U.S.) were reevaluated using greenhousegrown, hand-pollinated fruit in 2004. Seedlings were planted in 3.8-liter pots with autoclaved media (BACCTO, Michigan Peat Co., Houston, TX) under supplemental lighting (18/6 h light/dark) at 21 to $25^{\circ} \mathrm{C}$. 'Vlaspik' was used as a commercial standard. Flowers were hand-pollinated to allow for simultaneous harvest of 7- and 14-day postpollination (dpp) age fruit. Although not all genotypes were tested at the same time, each harvest included control 'Vlaspik' fruit. Inoculation was performed as described above: each inoculation tray included 7 and $14 \mathrm{dpp}$ test and 'Vlaspik' fruit. Harvests were performed on at least two dates for each genotype; multiple trays were tested for each genotype. At least five fruit of each age were tested for each genotype. Fruit were observed initially at $4 \mathrm{dpi}$, then maintained for further evaluation until $10 \mathrm{dpi}$, and scored for presence of water-soaked lesions and pathogen sporulation.

Fruit age. The commercial pickling standard, 'Vlaspik,' was grown in a research greenhouse at MSU during spring 2004. Flowers were hand-pollinated at 2to 3-day intervals to ensure a range of fruit ages from 2 to $18 \mathrm{dpp}$ at the day of harvest. Harvested fruit were washed with distilled water, air-dried, and measured for length and diameter. The fruit were placed arbitrarily in aluminum trays, then inoculated with $P$. capsici and incubated as described above. Fruit were observed daily for water-soaking symptoms and sporulation until $10 \mathrm{dpi}$. The experiment was conducted three times with approximately 15 to 20 fruit per experiment. The candidate resistant PIs identified in cucumber screen

Table 2. Rescreened cucumber (Cucumis sativus) cultigens that exhibited reduced pathogen sporulation after fruit inoculation with Phytophthora capsici

\begin{tabular}{|c|c|c|c|c|c|c|c|c|c|c|}
\hline \multirow[b]{3}{*}{ Cultigen } & \multirow[b]{3}{*}{ Source/year (when available) } & \multicolumn{3}{|c|}{ Mean disease ratings $^{\mathrm{a}}$} & \multirow{2}{*}{\multicolumn{6}{|c|}{ Years screened }} \\
\hline & & \multirow{2}{*}{$\begin{array}{c}\text { Sporulation } \\
\text { density }\end{array}$} & \multirow{2}{*}{$\begin{array}{c}\text { Sporulation } \\
\text { diameter }\end{array}$} & \multirow{2}{*}{$\begin{array}{c}\text { Lesion } \\
\text { diameter }\end{array}$} & & & & & & \\
\hline & & & & & 99 & $\mathbf{0 0}$ & 01 & $\mathbf{0 2}$ & $\mathbf{0 3}$ & 04 \\
\hline PI 163213 & USDA Bureau of Plant Industry, 1948 & 0.5 & 0.7 & 4.7 & + & + & & & & \\
\hline PI 197085 & U.S. Embassy, 1951 & 1.0 & 1.7 & 4.4 & & & + & + & & \\
\hline PI $197088^{b}$ & U.S. Embassy, 1951 & 0.6 & 1.3 & 4.9 & + & + & + & + & & \\
\hline PI 209069 & H.J. Heinz Co., 1953 & 1.0 & 1.7 & 5.0 & + & + & & & & \\
\hline PI 211979 & Office of Agricultural Attache, Tehran, 1953 & 1.0 & 3.3 & 5.9 & + & + & & & & \\
\hline PI 227209 & USDA ARS, 1955 & 1.0 & 2.5 & 5.3 & + & + & & & & \\
\hline PI 249561 & Eastern States Exchange, 1958 & 1.0 & 1.5 & 6.7 & & + & + & & & \\
\hline PI $249562^{b}$ & Eastern States Exchange, 1958 & 0.7 & 1.0 & 5.3 & + & + & + & + & & \\
\hline PI 257486 & Harbin College of Agriculture, 1959 & 1.0 & 2.5 & 5.7 & & & & & + & + \\
\hline PI 271326 & USDA ARS, 1961 & 0.8 & 1.3 & 5.9 & & & + & + & & \\
\hline PI $271327^{\mathrm{b}}$ & USDA ARS, 1961 & 1.0 & 0.7 & 5.1 & & + & + & + & & \\
\hline PI $271328^{b}$ & USDA ARS, 1961 & 1.0 & 1.4 & 4.7 & + & + & & & + & \\
\hline PI 279466 & Japanese Seed Growers Coop., 1962 & 1.0 & 2.9 & 5.6 & + & + & & & & \\
\hline PI 279467 & Japanese Seed Growers Coop., 1962 & 0.5 & 0.5 & 4.5 & + & + & & & & \\
\hline PI 279468 & Japanese Seed Growers Coop., 1962 & 0.7 & 1.9 & 5.6 & + & + & & & & \\
\hline PI $321008^{\mathrm{b}}$ & Taiwan Agricultural Research Institute, 1967 & 0.9 & 1.3 & 5.2 & + & + & + & & + & \\
\hline PI 330628 & AID Mission to Pakistan, 1968 & 1.0 & 2.2 & 4 & + & + & & & & \\
\hline PI 358813 & Louisiana State University, 1971 & 1.0 & 1.9 & 6.1 & + & + & & & & \\
\hline PI 390240 & Veg. and Ornamen. Res. Stn., 1974 & 1.0 & 2.6 & 5.2 & + & + & & & & \\
\hline PI $390262^{b}$ & Veg. and Ornamen. Res. Stn., 1974 & 1.0 & 2.4 & 5.8 & + & + & + & & & \\
\hline PI 391570 & Acad. of Ag. and Forestry Sciences, 1974 & 1.0 & 2.9 & 4.8 & + & & & & + & \\
\hline PI 422180 & Inst. of Genetics and Plant Breeding, 1977 & 0.7 & 1.1 & 2.6 & & & & & + & + \\
\hline PI 422182 & Inst. of Genetics and Plant Breeding, 1977 & 1.0 & 2.5 & 4.4 & + & & & & + & \\
\hline PI 426169 & Veg. Crops Division, 1978 & 1.0 & 3.5 & 8.1 & + & + & & & & \\
\hline PI 426170 & Veg. Crops Division, 1978 & 0.8 & 1.6 & 5.5 & + & + & & & & \\
\hline PI 432867 & Beijing Acad. of Ag. and Forestry, 1979 & 1.0 & 3 & 6.0 & + & + & & & & \\
\hline PI 618861 & Inst. of Veg., Agriculture, and Forestry, 1986 & 0.7 & 1.3 & 3.9 & & & & & + & + \\
\hline Ames 13333 & Tecnica Sup. De Ing. Agr., 1985 & 0.6 & 1.5 & 5.2 & & & & + & + & \\
\hline Ames $3944^{\mathrm{b}}$ & USDA, ARS, NERPIS, 1963 & 0.8 & 1.8 & 3.4 & & & & + & + & + \\
\hline Ames 3950 & USDA, ARS, NERPIS, 1983 & 1.0 & 3.7 & 6.5 & & & & + & + & \\
\hline Ames 7744 & Asgrow Seed Co., 1987 & 1.0 & 4.2 & 6.5 & & & & + & + & \\
\hline Arabian & Seminis Veg. Seeds, Asgrow Seed Co., 1999 & 1.0 & 1.9 & 6.4 & & + & + & & & \\
\hline Campbell 4177 & Seminis Veg. Seeds & 0.3 & 0.4 & 1.9 & & & & & + & + \\
\hline Cross Country & Ferry-Morse, 1987 & 1.0 & 3 & 2.5 & + & & & & & + \\
\hline Discover $^{\mathrm{b}}$ & Asgrow Seed Co., 1987 & 1.0 & 2.5 & 6.1 & + & + & + & + & & \\
\hline Excel $^{\mathrm{b}}$ & Asgrow Seed Co., 1993 & 1.0 & 2.9 & 6.4 & + & + & + & + & & \\
\hline Fancipak & Asgrow Seed Co., 1985 & 1.0 & 5.8 & 5.2 & + & & & & & + \\
\hline Fanfare & Petoseed, 1990 & 0.7 & 0.9 & 1.5 & & & & & + & + \\
\hline Lafayette & Sunseeds (Nunhems) & 1.0 & 3.6 & 7.8 & + & + & & & & \\
\hline Stallion & Seminis Veg. Seeds, Asgrow Seed Co., 1998 & 1.0 & 2.5 & 6 & & + & + & & & \\
\hline Thunder & Asgrow Seed Co., 1993 & 0.8 & 1.1 & 7.3 & & + & & & & + \\
\hline Thunderbird & Seminis Veg. Seeds-Petoseed, 1999 & 0.9 & 1.5 & 3.4 & & & & & + & + \\
\hline Vlaspik $^{\mathrm{b}}$ & Campbell (Vlasic)-Asgrow Seed Co., 1994 & 1.3 & 2.8 & 7 & & + & & & + & + \\
\hline Vlaspik+M Hybrid & Asgrow Seed Co. & 1.1 & 1.3 & 6.0 & & + & + & & & \\
\hline Vlasspear ${ }^{b}$ & Seminis Veg. Seeds & 2.2 & 4.6 & 7.0 & & + & & + & + & + \\
\hline Total & & & & & 25 & 29 & 13 & 12 & 16 & 12 \\
\hline
\end{tabular}

${ }^{a}$ Mean disease ratings of sporulation density, sporulation diameter, and lesion diameter are presented for each cultigen, 1999 to 2004 . Ratings for each cultigen are means from repeated fruit inoculations across years screened.

${ }^{\mathrm{b}}$ Cultigens that consistently performed with limited pathogen sporulation for $>2$ years. 
2 also were tested for effect of fruit age using hand-pollinated greenhouse-grown fruit harvested at 7 and $14 \mathrm{dpp}$ as described above.

Fruit age experiments were also conducted using fruit from field-grown plants. The slicing cucumber cultivar Straight Eight was grown at the MSU HRTC in fields with no history of $P$. capsici during the summer of 2004 using standard management practices (3). Cucumber fruit representing a range of sizes ( 2 to $22 \mathrm{~cm}$ in length) were harvested on four dates (26 August, 3 September, 8 September, and 10 September); 15 to 20 unblemished fruit were tested per harvest date. Fruit were prepared, inoculated, incubated, and rated for resistance as described above.

\section{RESULTS}

Screening methodology. The mycelial/sporangial plug inoculation method using microcentrifuge tubes was an effective screening method for establishing $P$. capsici infection on susceptible non- wounded cucumber fruits. Covering the inoculum plugs with microcentrifuge tubes was preferable, as uncovered plugs rapidly desiccated and disease did not progress. Zoospore inoculations yielded fruit symptoms similar to those observed with mycelial plugs, but with less consistency. Zoospores require water, but applying uniform-sized droplets on the hydrophobic surface of the cucumber fruit was difficult.

The four $P$. capsici isolates representing different $\mathrm{CT}$ s and mefenoxam sensitivities did not differ significantly for any of the three disease parameters measured on 66 cultigens in 1999 and 58 cultigens in 2000. All four isolates induced sporulating lesions of approximately $2.8 \mathrm{~cm}$ in diameter and sporulation density of 1.5 at $3 \mathrm{dpi}$; similar results were observed for lesion diameter (all approximately $6.0 \mathrm{~cm}$ ). Therefore, a single isolate, OP97, was selected to carry out all subsequent cultigen inoculations.

Germ plasm screening. Cucumber screen 1. Of the 333 cultigens evaluated in the first screen, 204 were PIs and 129 were commercial cultivars. No cultigens exhibited complete fruit resistance to $P$. capsici infection. However, $15 \%$ of the PIs and $11 \%$ of the commercial cultivars exhibited limited sporulation (e.g., sporulation densities $\leq 1.0$ ) (Fig. 1A and B, and Table 2). More than half of the cultigens had watersoaked lesions of $<3.0 \mathrm{~cm}$ (Fig. 1C). Promising cultigens that were rescreened either failed to again exhibit limited sporulation $(\leq 1.0)$ and were abandoned, or exhibited limited sporulation and were further evaluated in subsequent years. All cultigens that were screened in more than 2 years exhibited consistently limited sporulation. Some of the least susceptible included the commercially available cultivars Discover, Excel, and Vlaspik (Table 2). No PIs were reproducibly less susceptible than 'Vlaspik' when retested in multiple years.

Cucumber screen 2. Most genotypes were rapidly infected and exhibited pathogen sporulation by 5 dpi (Fig. 2). When the evaluation was extended to $10 \mathrm{dpi}$, infec-

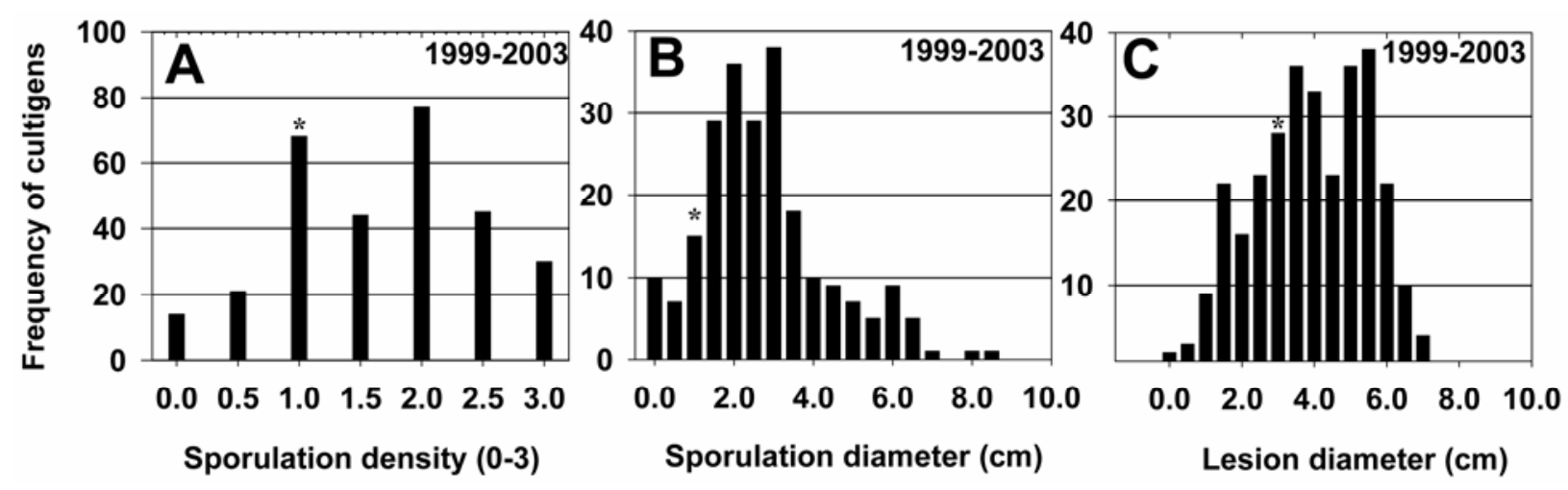

Fig. 1. Disease parameters of cultigens from germ plasm resistance screen 1. A, Sporulation density, B, sporulation diameter, and $\mathbf{C}$, lesion diameter measured from cucumber fruit inoculated with Phytophthora capsici OP97. Number of cultigens are cumulative from 1999 to 2003 . Sporulation density was rated as follows: $0=$ no sporulation, $1=$ light sporulation, $2=$ moderate sporulation, and $3=$ heavy sporulation. Asterisks indicate where the cucumber standard 'Vlaspik' disease ratings fell in comparison with other screened cultigens. No statistical analysis was performed on this disease data.

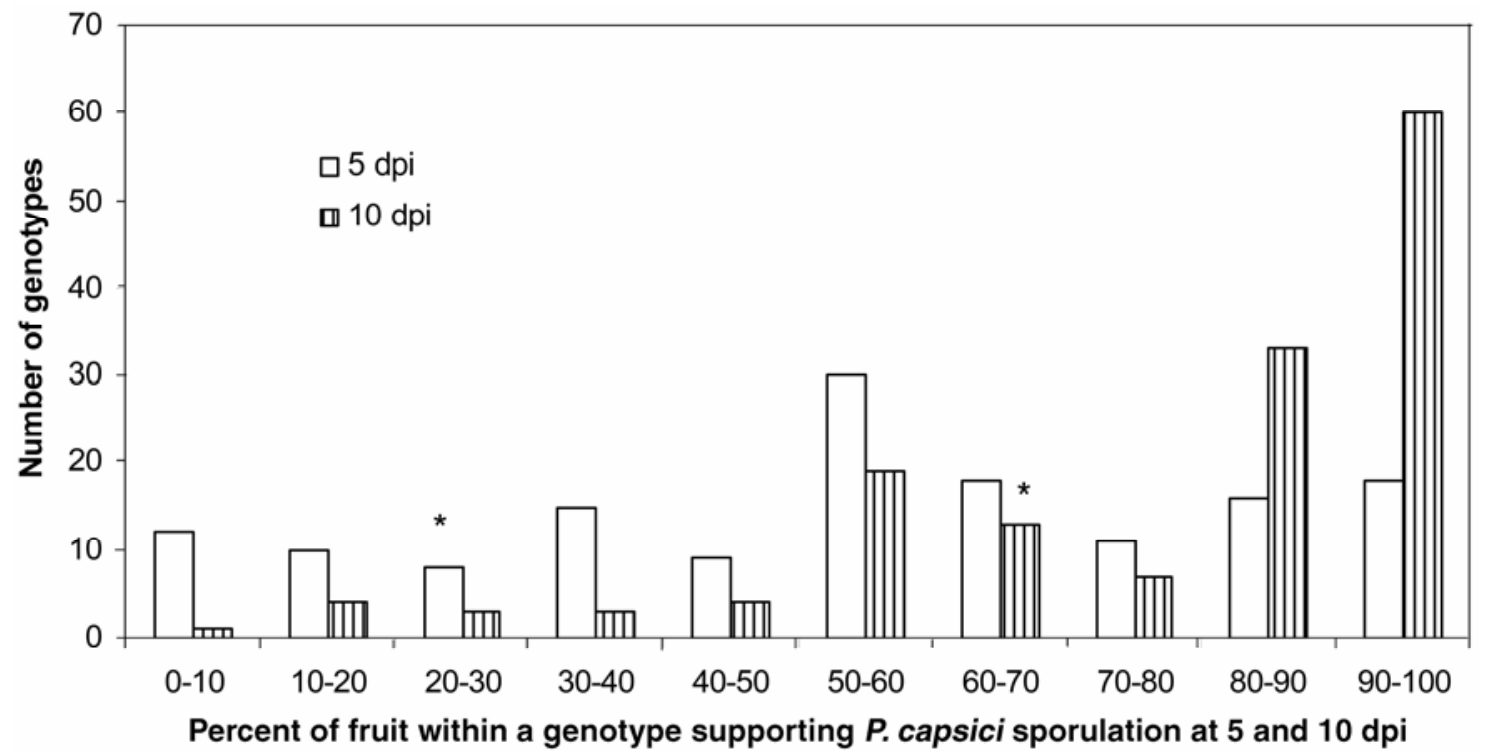

Fig. 2. Frequency distribution of number of cucumber genotypes for which sampled fruit showed the indicated sporulation (\%) at 5 (blank bar) and 10 (striped bar) days postinoculation (dpi). Asterisks (*) indicate 'Vlaspik' value. 
tion levels increased, with approximately $90 \%$ of the PIs exhibiting sporulation on $>50 \%$ of the fruit tested (Fig. 2). When accessions exhibiting a low percentage of fruit with pathogen sporulation were rescreened in 2004, all were as susceptible as the commercial 'Vlaspik' standard.

Fruit age. Symptom development on 'Vlaspik' fruit that were included as controls in each tray of the germ plasm screen 2 was inconsistent. Smaller, younger fruit appeared to be more susceptible, while larger, older fruit were less frequently infected. To directly test the effect of fruit age, greenhouse-grown, hand-pollinated fruits of known ages were compared for response to inoculation with $P$. capsici (Fig. 3). At 4 dpi, most fruit younger than 10 dpp exhibited sporulation, whereas fruit at $14 \mathrm{dpp}$ or older generally remained symptom-free (Fig. 3A to C). Fruit of intermediate ages (10 to $14 \mathrm{dpp}$ ) often exhib- ited water-soaked regions without sporulation. When fruit were scored again at 10 dpi, $83 \%$ of fruit with water-soaked lesions at 4 dpi had progressed to sporulation; however, $86 \%$ of fruit with no symptoms at 4 dpi remained symptom-free. Symptom-free fruit were usually oversized for pickling cucumbers (length $>14 \mathrm{~cm}$, diameter $>4.5 \mathrm{~cm}$ )

The transition from susceptible to more resistant appeared to coincide with the
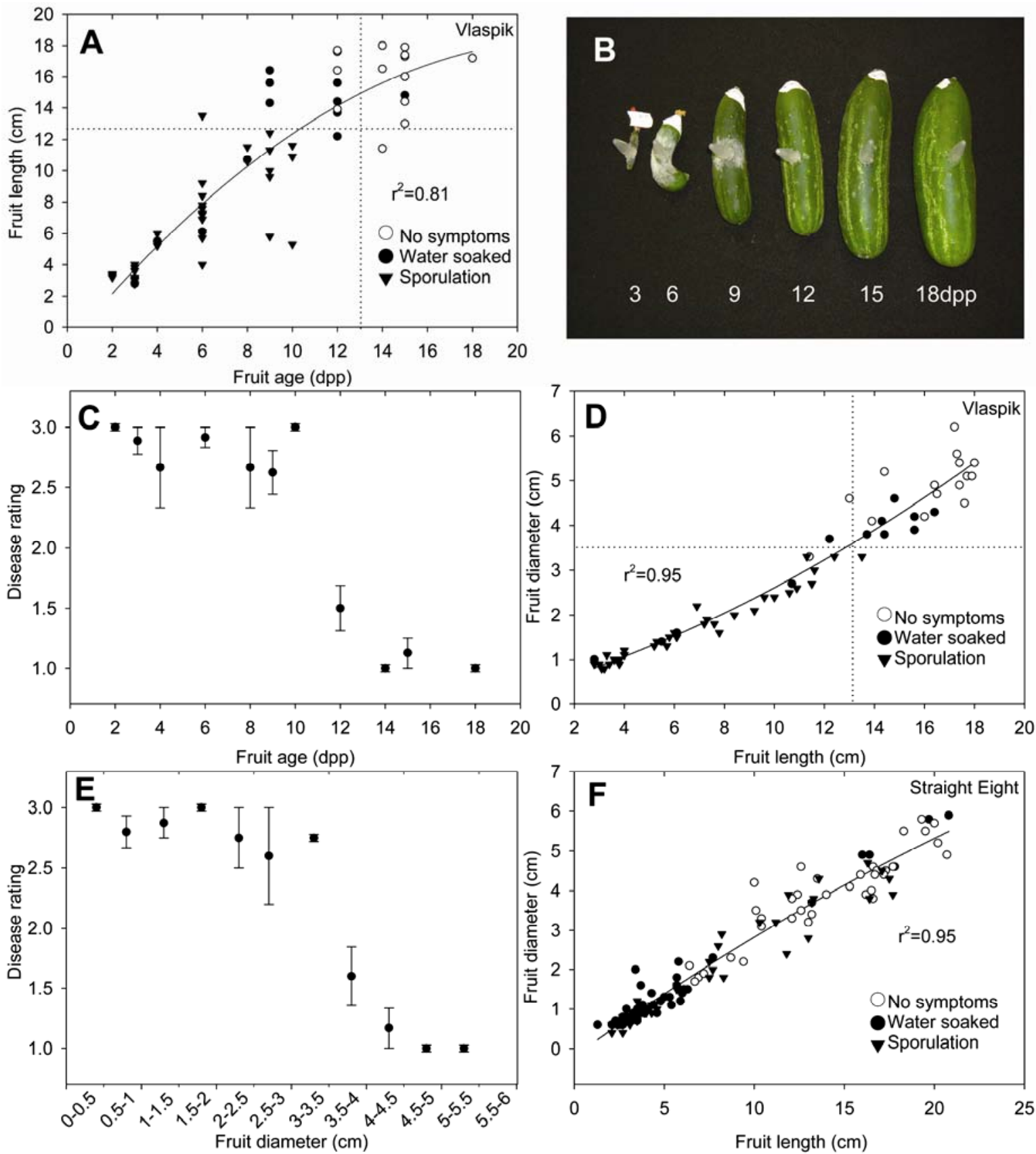

Fig. 3. Relationship between cucumber fruit age and size, and response to inoculation with Phytophthora capsici. A to E, Response of greenhouse-grown, hand pollinated fruit. Greenhouse fruit age experiments were repeated three times with approximately 15 to 20 fruit per experiment. The same trends were observed in each experiment. Data presented are pooled from the three experiments. A, Response of greenhouse-grown, hand-pollinated 'Vlaspik' fruit to $P$. capsici inoculation in relation to fruit age and length. B, Response of 'Vlaspik' fruit of various ages to inoculation with $P$. capsici. C, Mean disease rating $( \pm$ SE) of fruit harvested at 3 to 18 days postpollination (dpp). Rating scale: $0=$ no symptoms, $1=$ water-soaking, and $2=$ sporulated; each point (with the exception of $18 \mathrm{dpp}$ ) is the mean of 3 to 12 fruits. D, Disease response in relationship to fruit diameter and length. E, Mean disease rating ( \pm SE) of cucumber fruit in relation to fruit diameter. Each point is the mean of 4 to 10 fruits. F, Disease response of inoculated field-grown 'Straight Eight' fruit in relationship to fruit diameter and length. Symptom data were taken at 4 days postinoculation (dpi). Data are pooled from fruit sampled on four dates. $r^{2}$ values refer to quadratic binomial indicating a change in the rate of growth over time. 
transition from the period of rapid fruit elongation to the period of increased fruit diameter (approximately $12 \mathrm{~cm}$ length, 3 $\mathrm{cm}$ width), with a sharp decline in disease rating when fruit diameter reached approximately $3.5 \mathrm{~cm}$ (Fig. 3A, D, and E). Field-grown cucumbers ('Straight Eight'), harvested to include a range of fruit sizes from 2 to $22 \mathrm{~cm}$ in length, were also tested for response to $P$. capsici inoculation. Although growth rate and size can be influenced by environmental conditions, the relationship between fruit size and disease susceptibility followed the same trend as observed with greenhouse-grown fruit (Fig. 3F).

Fruit age effect was further examined with the candidate genotypes identified in germ plasm screen 2 using both 7 and 14 dpp fruit to target pre- and post-transitional stages based on the 'Vlaspik' results. At 7 dpp, the majority of fruit from all genotypes supported sporulation; the remainder developed water-soaked regions (Fig. 4). At $14 \mathrm{dpp}$, fruit from three of the five candidate genotypes (PIs: 263047, 288990, and 304805) were significantly ( $t$ test, $P \leq$ $0.05)$ less susceptible than at $7 \mathrm{dpp}$, with most of these fruit showing water-soaking or no symptoms rather than sporulation. In no case were older fruit more susceptible than younger fruit.

\section{DISCUSSION}

As $P$. capsici becomes more prevalent on vegetable crops in the United States (8), it would be highly valuable to identify host plant resistance to the pathogen for incorporation into a disease management strategy. For cucumber crops, fruit resistance is crucial because fruit, which are the marketable portion of the plant, also appear to be the most susceptible part of the plant. Thus, an essential first step is the establishment of reliable screening procedures specifically targeted for cucumber fruit.

Our screening methodology using nonwounded cucumber fruit inoculated with covered plugs of $P$. capsici incubated at high humidity for 3 days was efficient and reproducible. The use of nonwounded fruit provided a more accurate simulation of the host-pathogen interaction under field conditions (19). The use of mycelial/ sporangial plugs as inocula allowed for more consistent infection than zoospore inoculum due to the difficulty in quantifying the number of zoospores in each droplet and assuring that each droplet remained intact on the fruit surface for 3 days. A single $P$. capsici isolate, OP97, was used for fruit inoculations. Isolate OP97 maintained consistent growth and virulence after repeated subculturing, and it has also been used extensively in previous studies as a robust A1 CT standard (11). Using a single isolate simplified our screening. It is important before initiating a screen, however, to verify the virulence of the selected $P$. capsici isolate on susceptible host tissue.

Over a 6-year period, we evaluated the commercially mature fruit of 480 (333 from screen 1 and 147 from screen 2) cucumber cultigens for resistance to $P$. cap- sici and found that none exhibited complete resistance to pathogen infection. However, some cultigens, including several commercial cultivars, had limited pathogen sporulation on fruit. None of the PIs performed consistently better than the best cultivars. Until a resistant source is developed, using cultivars that limit pathogen sporulation may be beneficial in managing field disease.

Overall disease on cucumber fruit in 2004 was less than that observed during 1999 to 2003, making it difficult to differentiate among genotypes; therefore, 2004 results were not included in the data summaries. The reduced disease development may be due to weather and/or cultigen selection. The average air temperature during the cucumber-growing season at the Plant Pathology Farm, MSU, was $20.0^{\circ} \mathrm{C}$ for 1999 to 2003, with 19 growing degree days (base 50), but only $18.0^{\circ} \mathrm{C}$ with 16 growing degree days in 2004. Cooler temperatures affect physiological development of cucumber fruit, which may have impacted sensitivity to fruit rot (16).

Physiological changes associated with fruit growth and development may explain changing susceptibility among fruit of different ages. Cucumber fruit rapidly elongate longitudinally until they reach mature size; elongation then ceases, while diameter of the fruit continues to expand (23). At this point, there was a marked drop in susceptibility. Fruit that exhibited pathogen sporulation were usually at the stage of rapid elongation; fruit with inter-

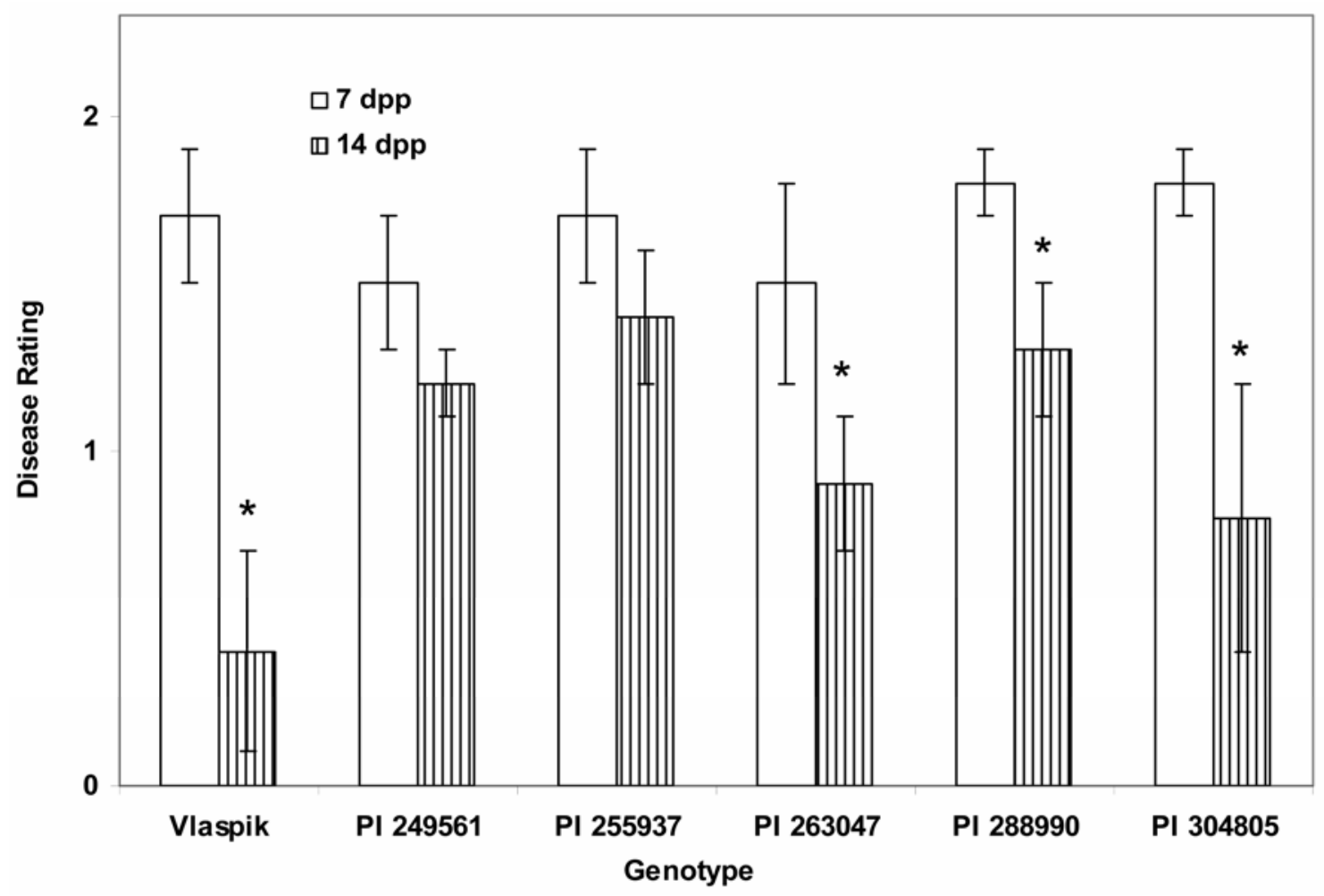

Fig. 4. Disease response of the candidate genotypes identified in cucumber screen 2 on greenhouse-grown hand-pollinated fruit harvested at 7 and 14 days postpollination (dpp). Fruit symptoms were scored for disease response at 4 dpi as: $0=$ no symptoms, $1=$ water-soaking, and $2=$ sporulated. Asterisks indicate that 7 and $14 \mathrm{dpp}$ fruit within a genotype were significantly different from each other, $t$ test $(P \bullet 0.05)$. Each value is the mean of minimum 5 fruit \pm SE. 
mediate symptoms were at the transition stage when fruit elongation slows down and diameter expansion begins; fruit that remained symptom-free were generally beyond the stage of rapid elongation. The transition in growth pattern likely also reflects other physiological changes associated with fruit development that may influence host-pathogen interactions.

The age- or size-related difference was observed for several genotypes, indicating that it is not unique to 'Vlaspik.' These observations have implications for appropriate screening procedures. If harvested fruits are too mature, age-dependent resistance may be observed that is not present throughout fruit development. This maturity factor could be responsible for the failure to observe resistance upon rescreening in several cases. The lack of significant decline in susceptibility between 7 - and 14-day-old fruit for two of the PIs may be due to genetic differences in susceptibility, or differences in rates of fruit development, such that $14 \mathrm{dpp}$ fruit are not physiologically equivalent among all PIs.

The changes in susceptibility among fruit of different ages occurred in both greenhouse and field conditions and so may have relevance for disease management strategies in the field. These observations suggest the importance of protecting the developing fruit from anthesis through the early period of rapid longitudinal growth, and may indicate optimum timings for fungicide applications.

In summary, we developed a direct cucumber fruit assay to screen for resistance to infection by $P$. capsici. Screening of approximately 500 cultigens did not identify a source of resistance superior to the partial resistance already present within several commercial cultivars. The screening process led to the observation that there are developmental differences in cucumber fruit susceptibility that can influence proper screening procedures and may also influence effective disease management strategies in the field.

\section{ACKNOWLEDGMENTS}

Research was funded by the Pickle and Pepper Research Committee of Michigan State University (Pickle Packers International, Inc.), Pickle Seed Research Fund (Pickle Packers International, Inc.), Project GREEEN (a cooperative effort by plantbased commodities and businesses with Michigan State University Extension, the Michigan Agricultural Experiment Station, and the Michigan Department of Agriculture), Michigan Department of Agriculture Specialty Crop Block Grant, and Michigan Agriculture Experiment Station. Thanks also to M. Bour, K. Cervantes, S. Linderman, and B. Cortright for technical assistance.

\section{LITERATURE CITED}

1. Ando, K., and Grumet, R. 2006. Evaluation of altered cucumber plant architecture as a means to reduce Phytophthora capsici disease incidence on cucumber fruit. J. Am. Soc. Hortic. Sci. In press.

2. Babadoost, M. 2004. Phytophthora blight: A serious threat to cucurbit industries. APSnet feature, Apr.-May. Online publication. American Phytopathological Society, St. Paul, MN

3. Bird, G., Bishop, B., Grafius, E., Hausbeck, M., Jess, L., Kirk, W., and Pett, W. 2005. Insect, Disease and Nematode Control for Commercial Vegetables. Michigan State University Ext. Bull. E-312, Cucumber section. pp. 55-61.

4. Bowers, J. H., and Mitchell, D. J. 1990. Effect of soil-water matric potential and periodic flooding on mortality of pepper caused by Phytophthora capsici. Phytopathology 80: 1447-1450.

5. Clark, R., Gabert, A., Munger, H., Staub, J., and Wehner, T. 1996. Cucumis sativus Crop Germplasm Committee Report. National Plant Germplasm System Crop Germplasm Committee List. Cucurbit CGC. Online publication.

6. Crossan, D. F., Haasis, F. A., and Ellis, D. E. 1954. Phytophthora blight of summer squash. Plant Dis. Rep. 38:557-559.

7. Erwin, D. C., and Ribeiro, O. K. 1996. Phytophthora Diseases Worldwide. American Phytopathological Society, St. Paul, MN.

8. Hausbeck, M. K., and Lamour, K. H. 2004. Phytophthora capsici on vegetable crops: Research progress and management challenges. Plant Dis. 88:1292-1303.

9. Hwang, B. K., and Kim, C. H. 1995. Phytophthora blight of pepper and its control in Korea. Plant Dis. 79:221-227.

10. Knerr, L. D., Staub, J. E., Holder, D. J., and May, B. P. 1989. Genetic diversity in Cucumis sativus L. assessed by variation at 18 allozyme coding loci. Theor. Appl. Genet. 78:119-128.
11. Lamour, K. H., and Hausbeck, M. K. 2000 Mefenoxam insensitivity and the sexual stage of Phytophthora capsici in Michigan cucurbit fields. Phytopathology 90:396-400.

12. Lamour, K. H., and Hausbeck, M. K. 2001. The dynamics of mefenoxam insensitivity in a recombining population of Phytophthora capsici characterized with amplified fragment length polymorphism markers. Phytopathology 91:553-557.

13. Lamour, K. H., and Hausbeck, M. K. 2001. Investigating the spatiotemporal genetic structure of Phytophthora capsici in Michigan. Phytopathology 91:973-980.

14. Lamour, K. H., and Hausbeck, M. K. 2003. Effect of crop rotation on the survival of Phy tophthora capsici in Michigan. Plant Dis. 87:841-845.

15. Lamour, K. H., and Hausbeck, M. K. 2003. Susceptibility of mefenoxam-treated cucurbits to isolates of Phytophthora capsici sensitive and insensitive to mefenoxam. Plant Dis. 87:920-922.

16. Medany, M. A., Wadid, M. M., and AbouHadid, A. F. 1999. Cucumber fruit growth rate in relation to climate. Acta Hortic. (ISHS) 491:107-112. Online publication.

17. Parra, G., and Ristaino, J. 1998. Insensitivity to Ridomil Gold (mefenoxam) found among field isolates of Phytophthora capsici causing Phytophthora blight on bell pepper in North Carolina and New Jersey. Plant Dis. 82:711.

18. Parra, G., and Ristaino, J. B. 2001. Resistance to mefenoxam and metalaxyl among field isolates of Phytophthora capsici causing Phytophthora blight of bell pepper. Plant Dis. 85:1069-1075.

19. Ristaino, J. B. 1991. Influence of rainfall, drip irrigation, and inoculum density on the development of Phytophthora root and crown rot epidemics and yield in bell pepper. Phytopathology 81:922-929.

20. Ristaino, J. B., and Johnston, S. A. 1999 Ecologically based approaches to management of Phytophthora blight on bell pepper. Plant Dis. 83:1080-1089.

21. Sy, O., Bosland, P. W., and Steiner, R. 2005 Inheritance of Phytophthora stem blight resistance as compared to Phytophthora root rot and Phytophthora foliar blight in Capsicum annuum L. J. Am. Soc. Hortic. Sci. 130:75-78.

22. Walker, S. J., and Bosland, P. W. 1999. Inheritance of Phytophthora root rot and foliar blight resistance in pepper. J. Am. Soc. Hortic. Sci. 124:14-18.

23. Wehner, T. C., and Saltveit, M. E. 1983. Photographic analysis of cucumber fruit elongation. J. Am. Soc. Hortic. Sci. 108:465-468. 